\title{
Health condition and colonization of stem insects in Scots pine after ground fire in Central Polissya
}

\author{
Olena Andreieva $\bowtie$, Olena Zhytova, Ivan Martynchuk
}

Zhytomyr National Agroecological University, Stary Bulv. 7, Zhytomyr, 10008, Ukraine, phone: +380963515130 , e-mail: andreeva-lena15@ukr.net

\section{Abstract}

Over the past decades, the increase in occurrence of fires has caused degradation of the forest ecosystem and caused impacts to the environment.

The aim of this study was to reveal the peculiarities of Scots pine health condition dynamics in the first 2 years after August fire and to estimate the rate of tree colonisation by stem insects in Central Polissya.

Scots pine health condition for the first 2 years after summer ground fire in August 2016 and the rate of tree colonisation by stem insects was studied in Zhytomyr region, Western Ukraine. Stem scorch height was measured for every fire-damaged tree, and the index of fire damage severity was calculated. Vital trees health condition worsened more intensively in the sample plot with the lowest relative stocking density and the highest stem scorch by fire. Generally, the forest health condition has worsened in post-fire period in fire damaged stands. However, $23.1 \%$ of trees recovered health condition from category 'drying-up' to 'severely weakened'. In fire-damaged stands, the number of species of stem insects has increased from 8 to 11 during the first 2 years of fire damage. Bark beetles were represented by Tomicus piniperda (Linnaeus, 1758), Tomicus minor (Hartig, 1834), Ips acuminatus (Gyllenhal, 1827) and Ips sexdentatus (Boerner, 1767). Jewel beetles included Anthaxia quadripunctata (Linnaeus, 1758), Phaenops cyaneus (Fabricius, 1775), Melanophila acuminata (DeGeer, 1774) and Chalcophora mariana (Linnaeus, 1758). Longhorn beetles included Monochamus galloprovincialis (Olivier, 1795), Pogonocherus fasciculatus (Degeer, 1775) and Acanthocinus aedilis (Linnaeus, 1758). Tree colonisation by stem insects in the year of fire damage was comparable with control stand, because insect swarming completed before this disturbance. Maximal occurrence of stem insects in 2017 in fire-damaged stand increased up to $66.7 \%$ (for I. sexdentatus). The percentage of trees colonised by any insect species at fire-damaged and healthy pine stands differed significantly. The occurrence of stem insects depended mainly on the ratio of trees with different health condition. Our results demonstrate data of tree damage from fire and tree health index as a strong predictor of post-fire mortality of Scots pine and bark beetle occurrence.

\section{KeY WORDS}

bark beetles, fire damage, forest health condition, ground fire, jewel beetles, longhorn beetles, Scots pine (Pinus sylvestris L.), stem scorch height 


\section{INTRODUCTION}

Stem insects (bark beetle and wood borers) colonise the trees after fire damage (Menges and Deyrup 2001; Lieutier et al. 2016). Bark beetles can cause mortality in fire-damaged trees that are not immediately killed by fire (McCullough et al. 1998; McHugh et al. 2003). Success of their attacks depends on fire severity (Demakov 2007; Santolamazza-Carbone et al. 2011), which is usually evaluated by stem scorch height and tree health condition (Lombardero and Ayres 2011; Meshkova and Zinchenko 2013). Scots pine (Pinus sylvestris Linnaeus 1753) trees are considered as moderately fire resistant and able to survive several low-intensity fires, which is related to tissue insulation from heat (Fernandes et al. 2008).

Research of slash pine (Pinus elliottii var. densa) in south-central Florida show that post-fire survival was most affected by season of burn, char height, area burned, insect attacks and stand composition (Menges and Deyrup 2001).

The interaction between fire and biotic agents of damage and mortality is still poorly studied.

Intensive Scots pine mortality was registered in $\mathrm{Re}-$ public Mari El (territory in the middle course of the Volga river) 2-5 years after fire, and the health condition was recovered only 15 years after fire (Demakov 2007). In the Left-bank Forest Steppe of Ukraine, Scots pine mortality made up $8.2 \%$ in the next year after fire, $7.3 \%$ in the 2 nd year and $1.7 \%$ in the 3rd year after fire, and the health condition returned to initial status at the 4th year (Meshkova and Zinchenko 2016). Such differences may be explained by quick loss of phloem humidity in the Left-bank Forest Steppe of Ukraine (Meshkova and Zinchenko 2013).

Healthy and slightly weakened trees can decline because of maturation feeding of some stem insects, particularly Tomicus piniperda (Linnaeus, 1758), Tomicus minor (Hartig, 1834) and Monochamus galloprovincialis (Olivier, 1795) (Meshkova and Nazarenko 2009; Meshkova et al. 2017), and because of their ability to vector the pathogens (Davydenko et al. 2014, 2017), particularly pinewood nematode, Bursaphelenchus xylophilus (Steiner \& Buhrer, 1934) (Nickle 1970; Haran et al. 2018).

Amongst many stem insect species, only about 10 of them may be harmful to forest stands depending on region. Mediterranean pines are attacked by both in- sects specific for region, Tomicus destruens (Wollaston, 1865), and common European species (T. piniperda, $T$. minor, Ips acuminatus (Gyllenhal, 1827), Ips sexdentatus (Boerner, 1767), etc.) (Faccoli et al. 2012; Lopez and Goldarazena 2012) The last 2 species were the most abundant also in the Left-bank Forest Steppe of Ukraine (Meshkova and Zinchenko 2013).

Species composition of stem insects depends on the date of fire and insect phenology (Demakov 2007; Meshkova et al. 2015, 2017a, b). In different natural zones in Ukraine, the dates of seasonal development were determined for the most common stem insects in relation with seasonal temperature (Meshkova et al. 2015). It was shown that after spring fire, the Scots pine can be colonised by many stem insects in the same year, and after fire in June, the trees can be colonised by the second generation of multivoltine insects, but after fire in August, stem insect attack would start only in the April of the next year and will be successful only if phloem humidity will be enough for larvae development (Meshkova and Nazarenko 2009; Meshkova and Zinchenko 2013).

The health condition of Scots pine forest after fire and the spread of stem insects after ground fire were not yet studied in Central Polissya. However, it is important for the estimation of the chance of forest health improvement and the limitation imposed on the duration of burned wood use.

The aim of this study was to reveal the peculiarities of Scots pine health condition dynamics in the first 2 years after August fire and to estimate the rate of tree colonisation by stem insects in Central Polissya.

\section{MAterial AND MEthodS}

Research was carried out in 2016-2017 in the Scots pine stands of Kornynske forestry in the State Enterprise 'Popilnyanske Forest Economy' in the south-eastern part of Zhytomyr region. The climate of the territory is a moderate continental with warm, wet summers and mild winters. The average annual air temperature is $6.8^{\circ} \mathrm{C}$, and the annual precipitation is $552 \mathrm{~mm}$.

In August 2016, a ground fire has happened in Kornynske forestry. Five sample plots (SP) were established in fire-damaged pine stands, and control plot was $1 \mathrm{~km}$ from them. All sample plots and control plot are 
Table 1. Characteristics of pure Scots pine stands in sample plots (SP) and in control plot (CP)

\begin{tabular}{|c|c|c|c|c|c|c|c|}
\hline $\begin{array}{c}\text { Sample plots (SP) } \\
\text { and control plot (CP) }\end{array}$ & $\begin{array}{c}\text { Latitude, } \\
\text { North }\end{array}$ & $\begin{array}{c}\text { Longitude, } \\
\text { East }\end{array}$ & $\begin{array}{c}\text { Age } \\
(\text { years })\end{array}$ & $\begin{array}{c}\text { Height } \\
(\mathrm{m})\end{array}$ & $\begin{array}{c}\text { Diameter } \\
(\mathrm{cm})\end{array}$ & $\begin{array}{c}\text { Relative } \\
\text { stocking } \\
\text { density }\end{array}$ & $\begin{array}{c}\text { Stock } \\
\left(\mathrm{m}^{3} / \mathrm{ha}\right)\end{array}$ \\
\hline SP 1 & $50^{\circ} 04^{\prime}$ & $29^{\circ} 31^{\prime}$ & 78 & 22.4 & 31.0 & 0.72 & 336 \\
\hline SP 2 & $50^{\circ} 03^{\prime}$ & $29^{\circ} 32^{\prime}$ & 85 & 23.2 & 28.6 & 0.50 & 242 \\
\hline SP 3 & $50^{\circ} 05^{\prime}$ & $29^{\circ} 33^{\prime}$ & 73 & 22.4 & 26.8 & 0.72 & 336 \\
\hline SP 4 & $50^{\circ} 02^{\prime}$ & $29^{\circ} 31^{\prime}$ & 85 & 23.3 & 28.8 & 0.76 & 333 \\
\hline SP 5 & $50^{\circ} 03^{\prime}$ & $29^{\circ} 33^{\prime}$ & 70 & 20.4 & 31.0 & 0.72 & 316 \\
\hline CP & $50^{\circ} 02^{\prime}$ & $29^{\circ} 34^{\prime}$ & 70 & 20.4 & 26.8 & 0.74 & 276 \\
\hline
\end{tabular}

Note: Sample plot (SP) - damaged by fire; control plot (CP) - without fire damage.

located in pine forest at fresh relative poor site conditions $\left(\mathrm{A}_{2}\right)$ with only Scots pine trees of $70-88$ years old. The average stem diameter is $26.8-31 \mathrm{~cm}$, and the average height of a tree is $20.4-23.4 \mathrm{~m}$. The relative stocking density is $0.5-0.76$ (Tab. 1).

Two weeks after fire (in August 2016), 100 trees in each sample plot and in control plot were labelled. Stem scorch height was measured for every fire-damaged tree and was categorised as more than $3 \mathrm{~m}$ (factor 3), within 0.5-3 m (factor 0.5 ) and below $0.5 \mathrm{~m}$ (factor 0.1). To calculate the index of fire damage severity, number of trees of each category of stem scorch height was multiplied by respective factor; results of multiplication were summed up and divided by the sum of the trees.

In every sample plot and control plot, the category of tree health condition was assessed for each tree 2 weeks after fire in August 2016 and in August 2017. Category of health condition was evaluated on a range of visual characteristics (crown density and colour, the presence and proportion of dead branches in the crown, etc.) according to 'Sanitary rules in the forests of Ukraine' (Meshkova and Zinchenko 2016). Each tree was classified into 1 of 6 categories of health condition (1st - healthy; 2nd - weakened; 3rd - severely weakened; 4th - drying-up; 5th - recently died; 6th - died over year ago). Indices of health condition for forest stand were calculated as mean weighted from trees number of each category of health condition for all trees ( $\mathrm{I}_{1-6}$ of the 1 st-6th categories) and for vital trees ( $\mathrm{I}_{1-4}$ of the 1 st -4 th categories).

Species composition of stem insects was identified by shape and structure of galleries as well as by insects caught in the galleries, on the stem surface or during maturation feeding.
A total of 30 trees of the 3 rd-5th categories of health condition were felled and barked in the stands near sample plots and near control plot in August 2016 and August 2017. Proportion of felled trees by categories of health condition corresponded to those in respective stands. During bark removing, the presence of particular stem insect species and their galleries was determined. Occurrence of each species was evaluated as the part of trees with its presence from total number of analysed trees in respective tree sample. As every tree was colonised by several insect species, the part of trees colonised with any insect species was evaluated to know their occurrence in the stands with and without fire damage in 2016 and 2017.

Statistical analyses included correlation analysis, $\chi^{2}$-test for comparison trees distribution by health condition and t-test for comparison of insects' occurrence using Statistica ${ }^{\circledR} 7.0$ (StatSoft, Inc., Tulsa, OK, USA).

\section{Results}

\section{Health condition of pine stands after ground fire}

Tree distribution by fire damage severity shows that fire was not intensive (Fig. 1).

Stem scorch height of more than $3 \mathrm{~m}$ was registered averagely in $2.8 \%$ trees, within $0.5-3 \mathrm{~m}$ in $5.6 \%$ trees and below $0.5 \mathrm{~m}$ in $91.6 \%$ trees. The percentage of trees with stem scorch height below $0.5 \mathrm{~m}$ was from $88 \%$ (SP 2) to $94 \%$ (SP 4). The percentage of trees with stem scorch height of more than $3 \mathrm{~m}$ was from $1 \%$ (SP 1 and SP 5) to 7\% (SP 2). Stem scorch height distribution is almost the same in all sample plots, except for 


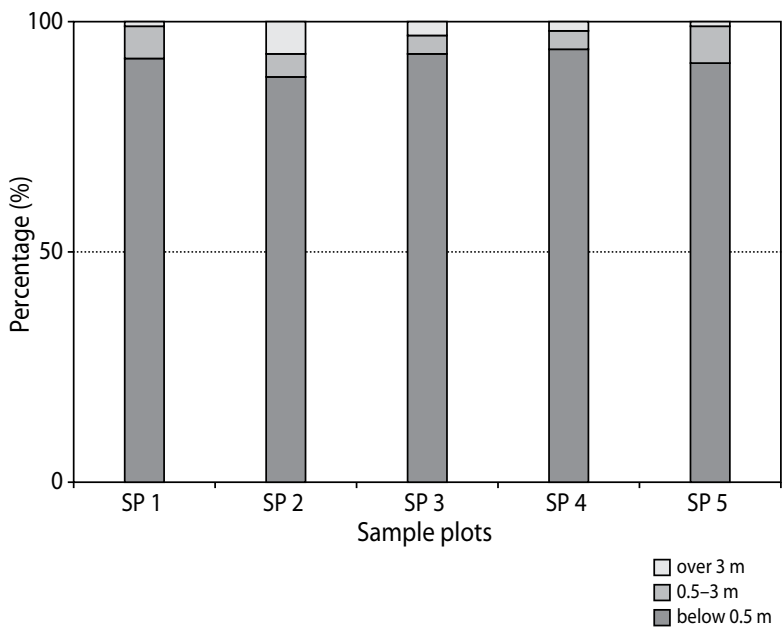

Figure 1. Distribution of Scots pine trees by fire damage severity (stem scorch height) in sample plots (SP) after ground fire

SP 2 $\left(\chi_{0.05}^{2}=6.0 ; \chi_{\text {fact }}^{2}=0.1-3.6\right.$ for sample plots SP 1, SP 3, SP 4 and SP 5; $\chi_{\text {fact }}^{2}=6.1-37.2$ for SP 2 with other sample plots).

Index of fire damage severity was 0.2 points for all sample plots and 0.3 for SP 2 (Tab. 2). In 2016, both health condition indices $\left(\mathrm{I}_{1-6}\right.$ for all trees and $\mathrm{I}_{1-4}$ for vital trees) were higher in all sample plots compared with control plot (without fire damage).

Health condition index for all trees $\left(\mathrm{I}_{1-6}\right)$ was 2.51 in control stand and 3.21-3.43 in fire-damaged stands (see Tab. 2).

This index takes into account the trees of the 6th category of health condition, which died more than a year before fire, and the trees of the 5th category of health condition, which died in the year of fire. The percentage of the 6 th category trees was $1 \%$ in the control plot and $0-5 \%$ in sample plots in fire-damaged stands and did not depend on the fire damage intensity. The percentage of the 5th category trees was 3.5-5.3 times greater in firedamaged stands (14-21\%) than in control one (4\%).

The health condition index for vital trees $\left(\mathrm{I}_{1-4}\right)$ was 2.37 in control stand and 2.71-2.98 in fire-damaged stands (see Tab. 2).

The trees of the 4th category of health condition dominated in all fire-damaged stands $(25-39 \%)$ and made up only $18 \%$ of all trees in the control plot.

The percentage of 'health' and 'weakened' trees was the highest in the control plot $(22 \%$ and $34 \%$, respectively) and made up only $10-17 \%$ and $14-22 \%$, respectively, in fire-damaged stands (see Tab. 2).

The health condition balance of trees for all firedamaged stands (SP 1-SP 5) significantly differed from control stands $\left(\chi_{0.05}^{2}=11.1 ; \chi_{\text {fact }}^{2}=45.6-102.5\right)$.

The ration between health condition of trees at SP 2 (with the highest stem scorch height index) significantly differed from that at SP $4\left(\chi_{\text {fact }}^{2}=14.8\right)$.

Health condition index meanings for all trees $\left(\mathrm{I}_{1-6}\right)$ were the same for SP 2 and SP 4, although the ratio of tree health condition was significantly different for these sites. It is connected with rather high percentage (39\%) of drying-up trees (the 4th category of health condition) in SP 2 and rather high percentage (5\%) of longtime dead trees (the 6th category of health condition).

The ration between health condition of vital trees significantly differed in fire-damaged stands and control stands without fire damage $\left(\chi_{0.05}^{2}=7.8\right.$;

Table 2. Health condition of Scots pine stands in 2016 in the sample plots after ground fire

\begin{tabular}{|c|c|c|c|c|c|c|c|c|c|}
\hline \multirow{2}{*}{$\begin{array}{l}\text { Sample } \\
\text { plots (SP) } \\
\text { and control } \\
\text { plot }(\mathrm{CP})\end{array}$} & \multirow[b]{2}{*}{$\begin{array}{c}\text { Index of } \\
\text { fire damage } \\
\text { severity }\end{array}$} & \multicolumn{6}{|c|}{ Trees distribution by health condition (\%) } & \multirow[b]{2}{*}{$\mathrm{I}_{1-4}$} & \multirow[b]{2}{*}{$\mathrm{I}_{1-6}$} \\
\hline & & $\begin{array}{c}1 \mathrm{st} \\
- \text { healthy }\end{array}$ & $\begin{array}{c}\text { 2nd } \\
\text { - weakened }\end{array}$ & $\begin{array}{c}\text { 3rd } \\
- \text { severely } \\
\text { weakened }\end{array}$ & $\begin{array}{c}4 \text { th } \\
\text { - drying-up }\end{array}$ & $\begin{array}{c}5 \text { th } \\
- \text { recently } \\
\text { died }\end{array}$ & $\begin{array}{c}\text { 6th } \\
- \text { died over } \\
\text { year ago }\end{array}$ & & \\
\hline SP 1 & 0.2 & 12 & 14 & 18 & 33 & 21 & 2 & 2.94 & 3.43 \\
\hline SP 2 & 0.3 & 13 & 15 & 19 & 39 & 14 & 0 & 2.98 & 3.26 \\
\hline SP 3 & 0.2 & 10 & 22 & 21 & 28 & 16 & 3 & 2.83 & 3.27 \\
\hline SP 4 & 0.2 & 17 & 14 & 22 & 25 & 17 & 5 & 2.71 & 3.26 \\
\hline SP 5 & 0.2 & 12 & 18 & 25 & 29 & 14 & 2 & 2.85 & 3.21 \\
\hline $\mathrm{CP}$ & 0 & 22 & 34 & 21 & 18 & 4 & 1 & 2,37 & 2,51 \\
\hline
\end{tabular}

Note: Sample plot (SP) - damaged by fire; Control plot (CP) - without fire damage; $\mathrm{I}_{1-4}$ - health condition index for vital trees (of the 1st-4th categories of health condition); $\mathrm{I}_{1-6}$ - health condition index for all trees (of the 1st-6th categories of health condition). 


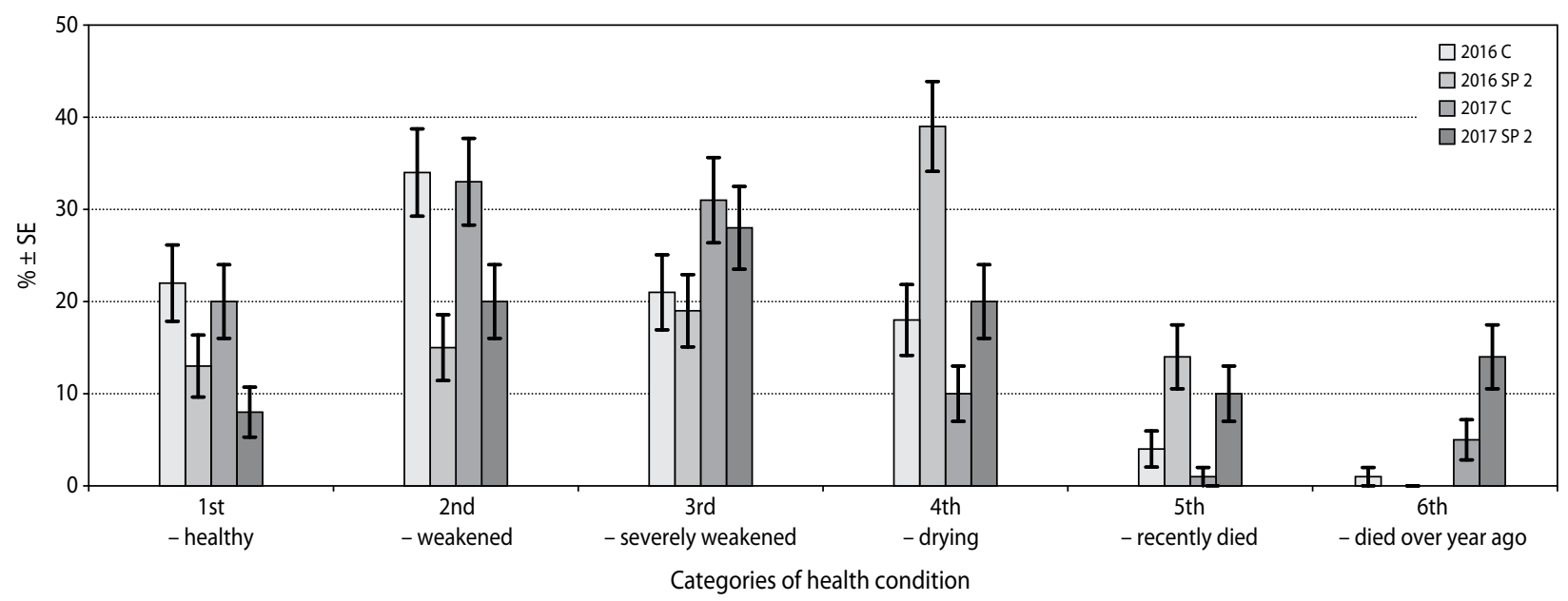

Figure 2. Distribution of Scots pine trees by categories of health condition in fire damaged plot (SP 2) and control plots (C) in 2016 (year of fire) and 2017 (year after fire): 2016C - control plots in 2016; 2016SP2 - sample plot 2 in 2016; $2017 \mathrm{C}$ - control plots in 2017; 2017SP2 - sample plot 2 in 2017

$\left.\chi_{\text {fact }}^{2}=15.7-41.8\right)$. Amongst the fire-damaged stands, SP 4 had the best health condition with the lowest $\mathrm{I}_{1-4}$ (2.71). Vital trees distribution by health condition in SP 4 significantly differed from other sample plots $\left(\chi_{\text {fact }}^{2}=7.9-9.3\right)$.

The percentage of 'drying-up trees' (the 4th category of health condition) has a positive correlation with the index of fire damage severity $\left(\mathrm{r}_{0.05}=0.75 ; \mathrm{r}=0.84\right)$.

In 2017, trees distribution by health condition changed in both fire-damaged and control plots (Fig. 2).

So in SP 2 with the highest fire damage in 2016, the percentage of healthy trees decreased from $13 \%$ to $8 \%$, the percentage of 'weakened' and 'severely weakened' trees increased from $15 \%$ to $20 \%$ and from $19 \%$ to $28 \%$, respectively, and the percentage of 'drying-up' trees decreased almost twice (from 39\% to 20\%). About half of such trees $(23.1 \%$ from all trees of the 4 th category of health condition in 2016) have improved their health condition to the 3rd category ('severely weakened trees'), whilst other ones died and made up the cohort of trees of the 5th category of health condition ('recently died'). All trees that have died in 2016 made up the cohort of trees of the 6th category of health condition in 2017.

In the control plot, the percentage of 'healthy' and 'weakened' trees (of the 1st and 2nd categories of health condition) almost did not change. The percentage of 'severely weakened' trees (the 3rd category of health condition) increased from $21 \%$ to $31 \%$, because some trees recovered from those trees that in 2016 were characterized by the 4th category of sanitation in 2016 (see Fig. 2).

The results of $\chi^{2}$ test show that Scots pine trees distribution by categories of health condition in all analysed groups (fire-damaged and control plots in 2017, fire-damaged plots in 2016 and 2017, and control plots in 2016 and 2017) significantly differs $\left(\chi_{0.05}^{2}=11.1\right.$; $\left.\chi_{\text {fact }}^{2}=22.1-65\right)$. Similar result was obtained when comparing only vital trees $\left(\chi_{0.05}^{2}=7.8 ; \chi_{\text {fact }}^{2}=8.5-41.8\right)$.

Health condition indices both for all pine trees and for vital pine trees in 2016 and 2017 were higher in firedamaged stands (Fig. 3).

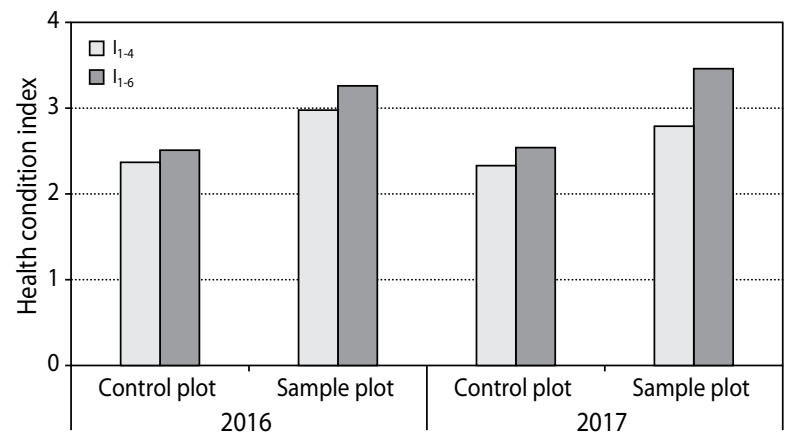

Figure 3. Indices of health condition $\left(\mathrm{I}_{1-4}-\right.$ for vital trees; $\mathrm{I}_{1-6}$ - for all trees) in fire-damaged (SP 2) and control (C) stands in 2016 (year of fire) and 2017 (year after fire)

Health condition index for all pine trees $\left(\mathrm{I}_{1-6}\right)$ has increased in fire-damage stand (SP 2) from 3.26 in 
2016 to 3.46 in 2017, that is, this stand was considered as drying one. However, some trees recovered in 2017 (see Fig. 2), and health condition index for vital trees decreased (2.98 and 2.79 in 2016 and 2017, respectively). It shows the possibility to stand to improve its health status. Health condition of control stand was almost the same in 2016 and $2017\left(\mathrm{I}_{1-4}\right.$ was 2.37 and 2.33, and $\mathrm{I}_{1-6}$ was 2.51 and 2.54 in 2016 and 2017, respectively).

\section{Stem insects in pine stands after ground fire}

In fire-damaged stands, 8 and 11 species of stem insects were found in 2016 and 2017, respectively (Fig. 4).

Family Curculionidae (subfamily Scolytinae) was represented by 4 species: Tomicus piniperda (Linnaeus, 1758), T. minor (Hartig, 1834), I. acuminatus (Gyllenhal, 1827) and I. sexdentatus (Boerner, 1767).

Four species were from Family Buprestidae: $A n-$ thaxia quadripunctata (Linnaeus, 1758), Phaenops cyaneus (Fabricius, 1775), Melanophila acuminata (DeGeer, 1774) and Chalcophora mariana (Linnaeus, 1758).

Three species were from Family Cerambycidae: M. galloprovincialis (Olivier, 1795), Pogonocherus fasciculatus (Degeer, 1775) and Acanthocinus aedilis (Linnaeus, 1758).

Amongst these species, T. piniperda and I. sexdentatus colonise the lower part of stem with thick bark; $T$. minor, I. acuminatus and P. fasciculatus colonise the upper part of stem with thin bark; and the rest of the species are able to colonise different parts of stem, which is characteristic for different regions (Demakov 2007; Lieutier et al. 2016; Meshkova and Zinchenko 2013).

Because the fire happened in August, most of stem insects have already completed their reproduction, and tree colonisation in 2016 was moderate $(23.3-30 \%$; see Fig. 4).

Analysis of Figure 4 shows that the occurrence of all stem insects in 2016 did not differ significantly in fire-damaged and control stands $\left(\mathrm{t}_{0.05}=2 ; \mathrm{t}_{\text {fact }}<0.3\right)$.

The occurrence of stem insects in control stands did not exceed $26.7 \%$ in 2016.

In 2017, the occurrence of 3 stem insects (M. galloprovincialis, Ph. cyaneus and A. quadripunctata) in control stands did not change $(26.7 \%, 23.3 \%$ and $13.3 \%$, respectively), the occurrence of 3 species (I. acuminatus, T. piniperda and T. minor) increased 1.1 times (up to $30 \%$; $\mathrm{t}_{\text {fact }}=0.3$ ) and the occurrence of 2 species (I. sexdentatus and A. aedilis) increased by a factor of 1.2 (up to $33.3 \% ; \mathrm{t}_{\text {fact }}=0.6$ ).

In 2017, 3 species were found in fire-damaged stands (M. acuminata, Buprestis mariana and P. fasciculatus), which were absent in fire-damaged stands in 2016 and in both years in control stands). However, the occurrence of these species in 2017 was rather low (13.3\%).

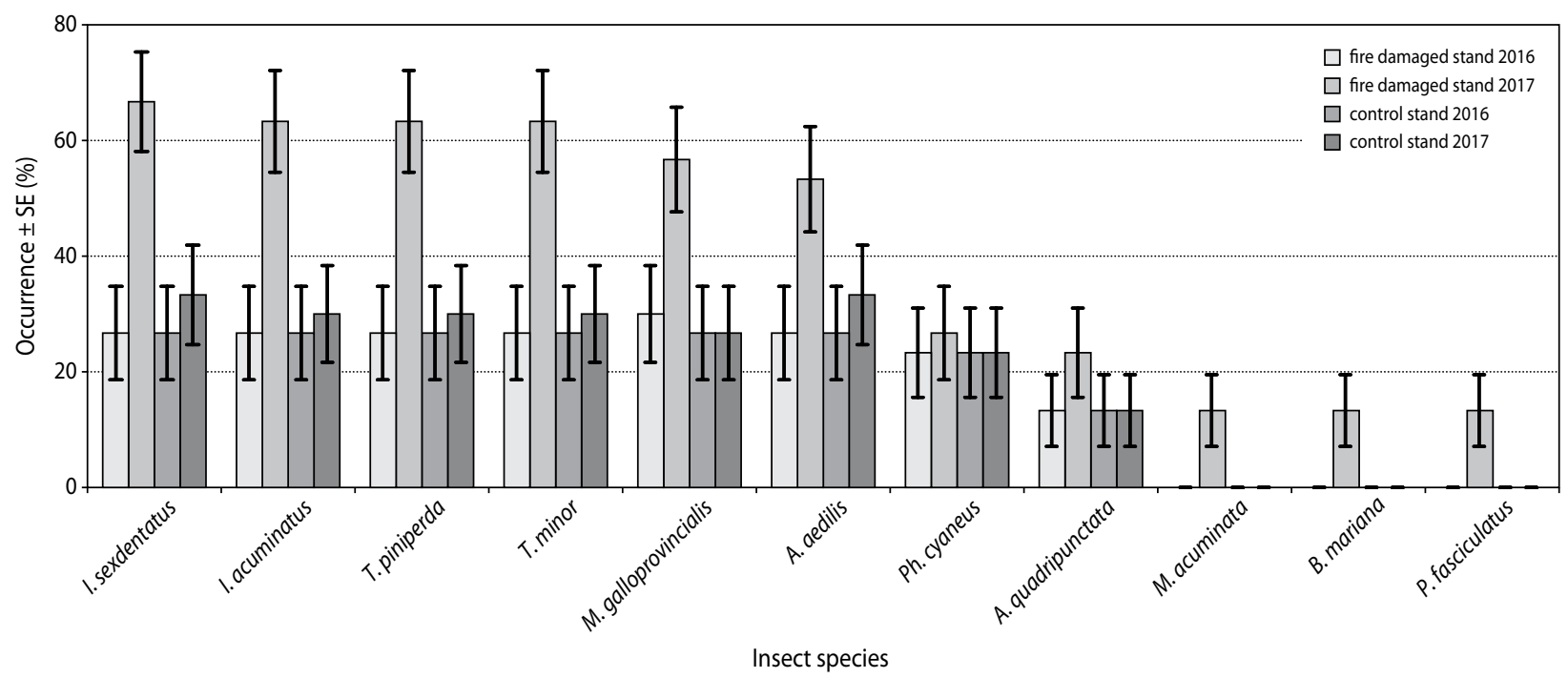

Figure 4. Occurrence of stem insects in fire-damaged and control stands in 2016 (year of fire) and 2017 (year after fire) (bars mean standard error) 
Table 3. Occurrence of stem insects in Scots pine trees of different health condition in fire-damaged and control stands in 2016 (year of fire) and 2017 (year after fire)

\begin{tabular}{|l|c|c|c|c|c|c|}
\hline \multirow{2}{*}{ Stand (year) } & \multicolumn{5}{|c|}{ Occurrence of stem insects in the trees of different health condition \pm SE $(\%)$} \\
\cline { 2 - 7 } & All trees & $\begin{array}{c}1 \text { st } \\
\text {-healthy }\end{array}$ & $\begin{array}{c}\text { 2nd } \\
\text { - weakened }\end{array}$ & $\begin{array}{c}\text { 3rd } \\
\text { - severely weakened }\end{array}$ & $\begin{array}{c}4 \text { th } \\
\text {-drying-up }\end{array}$ & $\begin{array}{c}5 \text { th } \\
- \text { recently died }\end{array}$ \\
\hline Control stand, 2016 & $\begin{array}{c}26.7 \pm 8.07 \mathrm{a} \\
(\mathrm{n}=30)\end{array}$ & $\begin{array}{c}0.0 \\
(\mathrm{n}=7)\end{array}$ & $\begin{array}{c}20.0 \pm 12.65 \\
(\mathrm{n}=10)\end{array}$ & $\begin{array}{c}14.3 \pm 13.23 \mathrm{c} \\
(\mathrm{n}=7)\end{array}$ & $\begin{array}{c}80.0 \pm 17.89 \mathrm{~d} \\
(\mathrm{n}=5)\end{array}$ & $\begin{array}{c}100.0 \\
(\mathrm{n}=1)\end{array}$ \\
\hline Fire damaged stand, 2016 & $\begin{array}{c}46.7 \pm 9.11 \mathrm{a} \\
(\mathrm{n}=30)\end{array}$ & $\begin{array}{c}0.0 \\
(\mathrm{n}=4)\end{array}$ & $\begin{array}{c}50.0 \pm 25.00 \\
(\mathrm{n}=4)\end{array}$ & $\begin{array}{c}16.7 \pm 15.21 \mathrm{e} \\
(\mathrm{n}=6)\end{array}$ & $\begin{array}{c}58.3 \pm 14.23 \mathrm{e} \\
(\mathrm{n}=12)\end{array}$ & $\begin{array}{c}100.0 \\
(\mathrm{n}=4)\end{array}$ \\
\hline Control stand, 2017 & $\begin{array}{c}30.0 \pm 8.37 \mathrm{a}) \\
(\mathrm{n}=30)\end{array}$ & $\begin{array}{c}0.0 \\
(\mathrm{n}=4)\end{array}$ & $\begin{array}{c}0.0 \\
(\mathrm{n}=11)\end{array}$ & $\begin{array}{c}40.0 \pm 15.49 \mathrm{f} \\
(\mathrm{n}=10)\end{array}$ & $\begin{array}{c}100.0 \mathrm{~g} \\
(\mathrm{n}=4)\end{array}$ & $\begin{array}{c}100.0 \\
(\mathrm{n}=1)\end{array}$ \\
\hline Fire damaged stand, 2017 & $\begin{array}{c}60.0 \pm 8.94 \mathrm{~b} \\
(\mathrm{n}=30)\end{array}$ & $\begin{array}{c}0.0 \\
(\mathrm{n}=2)\end{array}$ & $\begin{array}{c}16.7 \pm 15.21 \\
(\mathrm{n}=6)\end{array}$ & $\begin{array}{c}60.0 \pm 15.49 \mathrm{~h} \\
(\mathrm{n}=10)\end{array}$ & $\begin{array}{c}88.9 \pm 10.48 \mathrm{~h} \\
(\mathrm{n}=9)\end{array}$ & $\begin{array}{c}100.0 \\
(\mathrm{n}=3)\end{array}$ \\
\hline
\end{tabular}

Notes: the number of analyzed trees (n) is between brackets; values with different letters are significantly different at a significance level of $\alpha=0.05$.

In fire-damaged stands in 2017, the occurrence of 4 bark beetles and 2 longhorn beetles has increased significantly. The occurrence of $I$. sexdentatus increased by a factor of 2.5 (from $26.7 \%$ to $66.7 \%$; $\mathrm{t}_{\text {fact }}=3.4$ ). The occurrence of I. acuminatus increased by a factor of 2.4 (from $26.7 \%$ to $63.3 \%$; $t_{\text {fact }}=3.1$ ). The occurrence of T. piniperda increased by a factor of 2.4 (from $26.7 \%$ to $\left.63.3 \% ; \mathrm{t}_{\text {fact }}=3.1\right)$. The occurrence of $T$. minor increased by a factor of 2.4 (from $26.7 \%$ to $63.3 \%$; $\mathrm{t}_{\text {fact }}=3.1$ ). The occurrence of $A$. aedilis and M. galloprovincialis increased by a factor of 1.9 (from 26.7 to $53.3 \%$; $\mathrm{t}_{\text {fact }}=2.2$ ) and 2 (from $30 \%$ to $56.7 \%$; $\mathrm{t}_{\text {fact }}=2.2$ ), respectively.

Every colonised tree was attacked by different species of stem insects. The percentage of trees colonised by any insect species (stem insects occurrence) was $26.7 \%$ and $46.7 \%$ in undamaged (control) and firedamaged stands (Tab. 3), but the difference was not significant $\left(\mathrm{t}_{0.05}=2 ; \mathrm{t}_{\text {fact }}=1.6\right)$. Stem insect occurrence in fire-damaged stands in 2017 was twice more than that in control stand $(60 \%$ and $30 \%$ in fire-damaged and control stands, respectively) and differed significantly $\left(\mathrm{t}_{0.05}=2 ; \mathrm{t}_{\text {fact }}=2.4\right)$. The differences in the occurrence of stem insects in both 2016 and 2017 in control stand $\left(\mathrm{t}_{0.05}=2 ; \mathrm{t}_{\text {fact }}=0.3\right)$ and fire-damaged stands were not significant $\left(\mathrm{t}_{0.05}=2 ; \mathrm{t}_{\text {fact }}=1.0\right)$.

Analysis of colonisation of the trees of different health condition by stem insects shows that healthy trees (the 1st category of health condition) were not attacked at all (see Tab. 3). All recently died trees (the 5th category of health condition) were colonised.

In 2016, weakened stands (the 2nd category of health condition) were colonised more often in fire- damaged stands than control stands, but no significant statistical difference was observed $\left(\mathrm{t}_{0.05}=2.2 ; \mathrm{t}_{\text {fact }}=1.1\right)$. In 2017, such trees in control stands were not colonised at all. The trees of the 3rd category of health condition ('severely weakened') and the 4th category of health condition ('drying-up') were colonised in both firedamaged and control stands in 2016 and 2017. The occurrence of stem insects in the trees of the 4th category of health condition was higher than that in the trees of the 3rd category of health condition, but the difference was significant only for the control stand both in 2016 $\left(\mathrm{t}_{0.05}=2.2 ; \mathrm{t}_{\text {fact }}=3.0\right)$ and in $2017\left(\mathrm{t}_{0.05}=2.2 ; \mathrm{t}_{\text {fact }}=3.9\right)$ (see Tab. 3).

The colonisation of pine trees of the 2 nd category of health condition was $1.4 \%$ and $5.8 \%$ in the 1 st and 2 nd years after fire. The colonisation of pine trees of the 3 rd category of health condition was $2.7 \%$ and $20.7 \%$ in the 1 st and 2 nd years after fire. The colonisation of pine trees of the 4th category of health condition exceeded $50.0 \%$ in the $1^{\text {st }}$ year after fire and it approached $100 \%$ in the next years except for several recovered trees.

\section{Discussion}

The health condition and bark beetles (Ips spp. and Dendroctonus spp.) attacks after fire in Ponderosa pine (Pinus ponderosa Dougl. ex Laws.) was studied in the southern part of the United States (McHugh and Kolb 2003; Breece 2008) in more details. McHugh and Kolb (2003) suggested evaluating crown damage 
by adding percent crown volume scorched and percent crown volume consumed by fire. Breece (2008) measured the extent of fire damage on each tree as bole char severity, char height and direction, percent of the bole circumference charred, percent of crown scorched by fire and percent of crown consumed by fire using the same procedures described in McHugh and Kolb (2003). Breece (2008) used the bole char severity rating system created by Ryan (1983): $0=$ no char, $1=$ light char on edges of bark plates, $2=$ bark uniformly black with the exception of inner depths of prominent fissures and bark characteristic discernable and 3 = bark deeply charred and bark characteristics not discernable.

However, Scots pine crown and bark structure differ from Ponderosa pine, and both climate characteristics and stem insects species are another in the region of our research. In our research, Scots pine crown damage by fire was almost absent, and stem char severity was almost similar in the whole scorch surface. Therefore, stem scorch height was the main parameter for fire severity estimation (see 'Material and methods').

It is known (Lynch et al. 2006; Demakov 2007; Jenkins et al. 2008; Meshkova and Zinchenko 2013, 2016) that survival of trees following fire depends on initial tree health, degree of injury, weather conditions and possibilities of stem insects to colonise trees. Tree mortality resulting from crown fire happens soon after fire, and tree mortality after ground fire and injury of the lower part of stem may be registered only in the next growing season. It may be explained by different tissue insulation from heat (Fernandes et al., 2008). Crown fire damages shoots and twigs with thin bark, resulting in the death of living tissues, and ground fire damages the part of stem with coarse bark.

We can also assume that it is connected with relatively low relative stocking density in this sample plot (see Tab. 1).

Thus, forest stand had close values of age, diameter and height in SP 2 and SP 4, but relative stocking density was 0.5 and 0.76 in SP 2 and SP 4, respectively, and stem scorch height was 0.3 and 0.2 , respectively.

Forest health condition index for all trees $\left(\mathrm{I}_{1-6}\right)$ was similar (3.26) for SP 2 and SP 4, because it reflected health condition of both vital and dead trees. At the same time, health condition index for vital trees $\left(\mathrm{I}_{1-4}\right)$ was 2.98 and 2.71 for SP 2 and SP 4, respectively. It means that condition of vital trees worsened more intensively in the sample plot with lower relative stocking density and higher stem scorch by fire.

The higher values of the both health condition indices $\left(\mathrm{I}_{1-6}\right.$ for all trees and $\mathrm{I}_{1-4}$ for vital trees) in the year of fire damage (2016), the greater percentage of trees of the 5 th category of health condition in all sample plots and the lower values of these indices in the control plot $\left(\mathrm{I}_{1-6}\right.$ $=2.51 ; \mathrm{I}_{1-4}=2.37$ ) suggest that tree mortality in firedamaged stand resulted from fire damage. The percentage of 'drying' trees (4th category of health condition) positively correlates with index of fire damage severity $\left(\mathrm{r}_{0.05}=0.75 ; \mathrm{r}_{\text {fact }}=0.84\right)$.

Forest health condition index for all trees $\left(\mathrm{I}_{1-6}\right)$ almost did not change in the control stand and worsened in the fire-damaged stands. However, some trees in firedamaged stands recovered in 2017 (see Fig. 2) and the lower health condition index for vital trees $(2.98$ and 2.79 in 2016 and 2017, respectively) show the possibility of improvement in the stand health status.

The similar situation was described after low severity fire damage in the Left-bank Forest Steppe of the Ukraine (Meshkova and Zinchenko 2013, 2016).

In our research in Central Polissya, the list of stem insects in pine stands after ground fire included the species with wide distribution, which are common for pine stands in different European regions (Demakov 2007; Meshkova and Nazarenko 2009; Lombardero and Ayres 2011; Faccoli et al. 2012; Meshkova and Zinchenko 2013).

According to the research (Meshkova 2017c), colonisation of $21-60 \%$ of trees by stem insects corresponds to a moderate level of their spread. Colonisation of less than $20 \%$ of trees corresponds to the low level of spread and that of more than $60 \%$ of trees corresponds to the high level of spread. Our research demonstrates that tree colonisation by stem insects was moderate in the year of the fire, because their swarming completed before this disturbance, and was comparable with the control stand (see Fig. 4).

In 2017 in control stands, the occurrence of 2 species (I. sexdentatus and $A$. aedilis) increased 1.2 times but did not exceed 33.3\% (see Fig. 4).

Different stem insects often colonise the trees almost simultaneously; sometimes some of them attach the butt and others attack the top or middle part of stem. Therefore, tree colonisation by any stem insect was 
evaluated for all felled model trees, taking into account the category of health condition of each tree. It was found that in 2016, the insect occurrence in fire-damaged and control stands was insignificantly different, and in the next year after fire, it increased up to $60 \%$ and $30 \%$ in fire-damaged and control stands, respectively, and became significantly greater in the fire-damaged stand. Differences between stem insect occurrences in the trees of the same category of health condition were insignificant. It means that occurrence of pest insects in fire-damaged and control stands depends mainly on tree distribution by health condition.

In the Left-bank Forest Steppe of the Ukraine, Scots pine colonisation by stem insects in the year of damage depended on the cause of damage and on initial tree distribution by health condition (Meshkova and Zinchenko 2013). In this study, colonisation of pine trees by stem insects increased the next year after fire and decreased on the 3rd year after damage. Stem pests did not colonise the trees of the 1st category of health condition.

In Mari El in the year after fire damage, stem insects colonised up to $27 \%$ of lateral stem surface and only $16 \%$ and $12 \%$ of it in the 2 nd and 3rd years, respectively, but in different stands, this value depended on fire severity and number of trees susceptible to colonisation (Demakov 2007).

Dependence of stem insects on the amount of suitable substrate, population growth with the increase in the number of severely weakened and drying trees, is well known. For example, T. minor in Mari El successfully colonised healthy trees if its abundance exceeded 6 families per $1 \mathrm{dm}^{2}$ of bark surface (Demakov 2007). Outbreak collapse after several years because of beetle competition after attaining certain density was also supported in France (Pineau et al. 2017). These authors evaluated the critical threshold of $I$. sexdentatus attacks to establish on trees, which was 142 attacks $/ 1 \mathrm{~m}^{2}$ of bark surface (53-177 attacks $\left./ \mathrm{m}^{2}\right)$.

Therefore, according to Meshkova (2017c), the background level of stem insect occurrence in firedamaged stands (in the year of fire, 2016) was low for A. quadripunctata (13.3\%) and moderate for other stem insects (from $23.3 \%$ for Ph. cyaneus to $30 \%$ for M. galloprovincialis). In 2017, the level of stem insect occurrence in fire-damaged stands was low (13.3\%) for $M$. acuminata, B. mariana and P. fasciculatus; moderate for jewel beetles (23.3\% and $26.7 \%$ for $A$. quadripunctata and $P h$. cyaneus, respectively) and for longhorn beetles (53.3\% and $56.7 \%$ for $A$. aedilis and M. galloprovincialis, respectively); and high for bark beetles (63.3\% for T. piniperda, T. minor and I. acuminatus and $66.7 \%$ for I. sexdentatus; see Fig. 4).

In the control stand without fire damage, stem insect occurrence in both 2016 and 2017 was moderate for all the 8 revealed species $(23.3-26.7 \%$ and $23.3-33.3 \%$, respectively).

Research of these insects seasonal development shows that their first attacks of pines start soon after tree vegetation begins (the 2nd half of March) and these attacks are almost uninterrupted in summer months (Meshkova et al. 2015, 2017a,b).

Therefore, the most effective way to reduce the risk of trees mortality that results from colonisation of stem insects is to immediately remove all felled dead and dying trees, which can be the substrate for these insects reproduction before these insects population grows large enough to attack healthy, less injured by fire or recovering trees.

\section{Conclusions}

Vital Scots pine trees condition $\left(\mathrm{I}_{1-4}\right)$ worsened more intensively in the sample plot with the lowest relative stocking density and the highest stem scorch by fire. In 2017, forest health condition almost did not change in control stand and worsened in fire-damaged stands. However, $23.1 \%$ of trees have recovered their health condition from category 'drying-up' to 'severely weakened'. In fire-damaged stands, 8 species of stem insects were found in 2016 and 11 species in 2017. They were T. piniperda, T. minor, I. acuminatus, I. sexdentatus (Curculionidae: Scolytinae), A. quadripunctata, Ph. cyaneus, M. acuminata, C. mariana (Buprestidae), M. galloprovincialis, P. fasciculatus and A. aedilis (Cerambycidae).

Tree colonisation by stem insects in the year of fire damage was comparable with control stand, because insect swarming completed before this disturbance. In 2017, I. sexdentatus was the most spread stem insect in fire-damaged stands ( $66.7 \%$ of trees). The occurrence of stem insects depended mainly on the ratio of trees with different health condition. 


\section{References}

Breece, C.R., Kolb, T.E., Dickson, B.G., McMillin, J.D., Clancy, K.M. 2008. Prescribed fire effects on bark beetle activity and tree mortality in southwestern ponderosa pine forests. Forest Ecology and Management, 255 (1), 119-128. DOI:10.1016/j. foreco.2007.08.026.

Davydenko, K., Vasaitis, R., Menkis, A. 2017. Fungi associated with Ips acuminatus (Coleoptera: Curculionidae) in Ukraine with a special emphasis on pathogenicity of ophiostomatoid species. European Journal of Entomology, 114, 77-85. DOI: 10.14411/ eje.2017.011.

Davydenko, K., Vasaitis, R., Meshkova, V., Menkis, A. 2014. Fungi associated with the red-haired bark beetle, Hylurgus ligniperda (Coleoptera: Curculionidae) in the forest-steppe zone in eastern Ukraine. European Journal of Entomology, 111 (4), 561-565. DOI: 10.14411/eje.2014.070.

Demakov, Yu.P. 2007. Post-pyrogenic dynamics of xylophilic entomocomplex in pine forests of Mari Polissya (in Russian with English summary). Scientific works of the State Nature Reserve "Bolshaya Kokshaga", 2, 248-302.

Faccoli, M., Finozzi, V., Colombari, F. 2012. Effectiveness of different trapping protocols for outbreak management of the engraver pine beetle Ips acuminatus (Curculionidae, Scolytinae). International Journal of Pest Management, 58 (3), 267-273. DOI: 10.1080/09670874.2011.642824.

Fernandes, P.M., Vega, J.A., Jimenez, E., Rigolot, E. 2008. Fire resistance of European pines. Forest Ecology and Management, 256 (3), 246-255. DOI:10.1016/j.foreco.2008.04.032.

Haran, J., Rousselet, J., Tellez, D., Roques, A., Roux, G. 2018. Phylogeography of Monochamus galloprovincialis, the European vector of the pinewood nematode. Journal of Pest Science, 91 (1), 247-257. DOI: $10.1007 / \mathrm{s} 10340-017-0878-4$.

Jenkins, M.J., Hebertson, E., Page, W., Jorgensen, C.A. 2008. Bark beetles, fuels, fires and implications for forest management in the Intermountain West. Forest Ecology and Management, 254 (1), 16-34. DOI:10.1016/j.foreco.2007.09.045.

Lieutier, F., Mendel, Z., Faccoli, M. 2016. Bark beetles of Mediterranean conifers. In: Insects and Diseases of Mediterranean Forest Systems (eds.: T. Paine, F. Lieutier). Springer, Cham. DOI: 10.1007/978-3-31924744-1_6.

Lynch, H.J., Renkin, R.A., Crabtree, R.L., Moorcroft, P.R. 2006. The influence of previous mountain pine beetle (Dendroctonus ponderosae) activity on the 1988 Yellowstone fires. Ecosystems, 9 (8), 1318-1327. DOI: 10.1007/s10021-006-0173-3.

Lombardero, M.J., Ayres M.P. 2011. Factors influencing bark beetle outbreaks after forest fires on the Iberian Peninsula. Environmental Entomology, 40, 1007-1018. DOI: 10.1603/EN11022.

Lopez, S., Goldarazena, A. 2012. Flight dynamics and abundance of Ips sexdentatus (Coleoptera: Curculionidae: Scolytinae) in different sawmills from Northern Spain: Differences between local Pinus radiata (Pinales: Pinaceae) and Southern France incoming $P$. pinaster Timber. Psyche (Cambridge), 1-6. DOI: $10.1155 / 2012 / 145930$.

McCullough, D.G., Werner, R.A., Neumann, D. 1998. Fire and insects in northern and boreal forest ecosystems of North America. Annual Review of Entomology, 43 (1), 107-127.

McHugh, C.W., Kolb, T.E., Wilson, J.L. 2003. Bark beetle attacks on ponderosa pine following fire in northern Arizona. Environmental Entomology, 32 (3), 510-522.

Meshkova, V.L., Nazarenko, S.V. 2009. Pine bark beetles as the indicators of consequences of forest fires in pine plantations of Kherson region (in Ukrainian with English summary). Forestry and Forest Melioration, 116, 36-44.

Meshkova, V.L., Zinchenko, O.V. 2013. Colonization by stem insects of pine plantations weakened by various factors (in Ukrainian with English summary). The Bulletin of Kharkiv National Agrarian University. Series Phytopathology and Entomology, 1/2, 126-131.

Meshkova, V.L., Zinchenko, O.V., Skrylnik, Yu.Ye., Aristova, A.I. 2015. The dates of development of pine stem pests in the Left-bank Ukraine (in Russian with English summary). Bulletin of the St. Petersburg Academy of Forestry, 211, 59-67.

Meshkova, V.L., Zinchenko, O.V. 2016. Prediction the change in the health condition of pine plantations, weakened by various factors, in the fresh relatively poor forest site conditions of the forest-steppe part 
of the Kharkiv region (in Ukrainian with English summary). Ukrainian Forest, 1, 83-89.

Meshkova, V.L., Kochetova, A.I., Zinchenko, O.V., Skrylnik Yu.Ye. 2017a. Biology of multivoltine bark beetles species (Coleoptera: Scolytinae) in the North-Eastern Steppe of the Ukraine. The Bulletin of Kharkiv National Agrarian University. Series Phytopathology and Entomology, 1/2, 117-124.

Meshkova, V.L., Skrylnik, Yu.Ye., Zinchenko, O.V., Kochetova, A.I. 2017b. Seasonal development of the pine sawyer beetle (Monochamus galloprovincial$i s$ ) in the north-eastern steppe of Ukraine. Forestry and Forest Melioration, 130, 223-230.

Meshkova, V.L. 2017c. Evaluation of harm (injuriousness) of stem insects in pine forest. Scientific Bulletin of UNFU, 27 (8), 101-104. DOI: 10.15421/40270816.
Pineau, X., Bourguignon, M., Jactel, H., Lieutier, F., Salle, A. 2017. Pyrrhic victory for bark beetles: successful standing tree colonization triggers strong intraspecific competition for offspring of Ips sexdentatus. Forest Ecology and Management, 399, 188-196. DOI: 10.1016/j.foreco.2017.05.044.

Ryan, K.C. 1983. Techniques for assessing fire damage to trees. In: Proceedings of the Symposium: Fire and its Field Effects (ed.: J.E. Lotan). Intermountain Fire Council, Missoula, MT, 2-10.

Santolamazza-Carbone, S., Pestana, M., Vega A.J. 2011. Post-fire attractiveness of maritime pines (Pinus pinaster Ait.) to xylophagous insects. Journal of Pest Science, 84, 343-353. DOI: 10.1007/s10340-0110359-0. 